\title{
Comment on: Shape memory Ni-Ti alloy swan-like bone connector for treatment of humeral shaft nonunion
}

\author{
Mrinal Sharma $\cdot$ Shalini Sharma
}

Received: 20 April 2010 / Accepted: 24 May 2010 / Published online: 18 June 2010

(C) Springer-Verlag 2010

\section{Dear Editor,}

We read with interest the article on "Shape memory Ni-Ti alloy swan-like bone connector for treatment of humeral shaft nonunion" [1]. We would like to congratulate the authors for the original and outstanding work and would like to raise some querries.

How was the implant sterilised? Does routine autoclaving have any effect on the material properties of the implant?

In our experience, while reducing nonunions, the bone adjacent to the fracture is often denuded of soft tissues (as is also seen in Fig. 2e of this article [1]) and the radial nerve is at risk. The authors have themselves in another study reported neuropraxia in 4:105 cases operated with shape memory connector [2].Moreover, the implant embraces the bone, and the radial nerve is further at risk. We would like to know how often the radial nerve was explored? A circumferentially placed implant is more likely to cause damage to vascularity.

How was the implant size to be placed decided? Were the patients given any postoperative supplementary stabilisation?

The authors state that implant removal was easy. If bone graft was placed around the implant, then at the time of removal, the implant should have been surrounded by bone, making the removal difficult.
Nitinol implants have been used in spine [3], noncemented hip replacement, and in staples for osteosynthesis [4]. What is the authors view on use of these implants in femur and forearm nonunions? Do they suggest shape memory connectors (SMC) to treat fresh fractures?

Corrossion resistance properties of Ni-Ti shape memory alloys have been questioned [5] and their in vitro behavior studied [6].The alloy has been stated to be comparable or inferior to steel. Biocompatability needs to be time tested.

\section{References}

1. Su JC, Liu XW, Yu BQ, Li ZD, Li M, Zhang CC (2010) Shape memory Ni-Ti alloy swan-like bone connector for treatment of for humeral shaft nonunion. Int Orthop 34(3):369-375

2. Su JC, Liu XW, Zhang CC, Guan HP, Li ZD, Cao LH (2008) Design and clinical application of swan-like memory connector for humeral shaft nonunion. J Orthopaedics 5(2):e16

3. Bansiddhi A, Sargeant TD, Stupp SI, Dunand DC (2008) Porous NITi for bone implants: A review. Acta Biomater 4:773-782

4. Mereau TM, Ford TC (2006) Nitinol Compression Staples for Bone Fixation in Foot Surgery. J Am Podiatr Med Assoc 96(2):102-106

5. Rondelli G (1996) Corrosion resistance tests on NiTi shape memory alloy. Biomaterials 20:2003-2008

6. Gil FX, Manero JM, Planell JA (1996) Relevant aspects in the clinical applications of NiTi shape memory alloys. J Mater Sci Mater Med 7(7):403-406

\footnotetext{
M. Sharma $(\bowtie)$

Department Orthopaedics, University College

of Medical Sciences,

New Delhi, India

e-mail: dr.mrinalsharma@gmail.com

S. Sharma

University College of Medical Sciences,

New Delhi, India
} 